\title{
\$ sciendo
}

\author{
Lohita Solanki \\ University of Warsaw
}

\section{INDIA-POLAND RELATIONS: TRANSFORMATION OF CULTURAL RELATIONS TO CULTURAL DIPLOMACY}

DOI: $10.2478 /$ ppsr-2020-0004

\begin{abstract}
Author
Lohita Solanki is an international relations scholar, focusing on soft power, diplomacy, and India-Poland relations. She is currently finishing her dissertation at the University of Warsaw. In 2016, she was awarded 'The University of Warsaw's Special Scholarship' to pursue her studies at the faculty of Political Science and International Studies. Prior to her PhD, she completed an M. Phil from the Institute of Foreign Policy Studies, University of Calcutta. She also did her Master's in International studies from Stella Maris College, Chennai. She has also done multiple internships at the Institute of Social Sciences, New Delhi before making her journey to Warsaw to pursue her PhD.
\end{abstract}

ORCID no. 0000-0003-2184-4838

e-mail: lohitasolanki@yahoo.com

\begin{abstract}
The principal aim of this article is to analyse how cultural relations between India and Poland have transformed into cultural diplomacy. For this purpose, the article traces the historical interactions of culture between the two countries that precede their creation as modern-day republics. The article analyses the various stages through which cultural engagement between India and Poland have progressed. The author presents culture as a binding factor as it is paving the way for deeper engagements between the two sides. Cultural diplomacy between India and Poland is opening new avenues of interactions which are reflected in their political and economic relationship. The article argues that the absence of a strategic partnership puts impetus on cultural diplomacy as it becomes an important foundational block on which a future relationship can be build.
\end{abstract}

Keywords: culture, diplomacy, India-Poland, art, history

\section{Introduction}

India and Poland are countries located in different continents. India belongs to South Asia, whereas Poland is a part of Central Europe. India became a free democratic country after gaining independence from Britain on $15^{\text {th }}$ August 1947. Poland, on the other hand, became a democracy after the revolution of 1989. Poland is ethnically homogenous. The culture too is homogenous in terms of language, food, and traditions. India is diverse with multiple cultures. The vast diversity in terms of languages, tribes, food, and traditions make India a unique country. Given the difference of cultures between the two countries there has been harmonious interaction which even predates their formation as independent states. This article will focus on how cultural relations between these two countries have progressed, especially emphasizing the fact that they have now transformed from merely being cultural relations to cultural diplomacy. The focus on cultural diplomacy 
juxtaposes with the development that can be seen in the fields of political, economic and security relations. The importance of Poland for India is increasing ever more given Warsaw's central role as a major power in Central and Eastern Europe. Similarly, for Poland, engaging with New Delhi's imperative given its foreign policy of diversifying its relations with countries outside of the European Union.

\section{Defining Culture}

Culture is defined as the arts and other manifestations of human intellectual achievement regarded collectively (Oxford Dictionaries, 2019). These 'manifestations' include all variations of the arts, educational opportunities, language, ideas, cuisines, religions, and sports (Rivera 2015, 8). When it comes to relations between two countries there are many aspects to it, for instance, political, economic, security social, and diplomatic. Culture focuses on the soft yet highly influential dimension of the relationship. Cultural relations focus on people to people engagement with the sharing of ideas, interests, and interactions. A distinction, however, needs to be made between cultural relations and cultural diplomacy. The former is a natural process that often goes back in history to when there was a natural interaction between different cultures, while the latter is a state-sponsored mindful and conscious process that gained prevalence in modern times. In the words of Ben O'Loughlin, Professor at Royal Holloway, University of London the difference between cultural relations and cultural diplomacy is that "Cultural diplomacy is a more specific term insofar as diplomacy is usually associated with states. States' public diplomacy is states liaising with publics in other states, so cultural diplomacy being states liaising with other states or their peoples through the medium of culture" (Rivera 2015, 9).

According to Richard Arndt, "Cultural relations ... means literally the relations between national cultures, those aspects of intellect and education lodged in any society that tend to cross borders and connect with foreign institutions. Cultural relations grow naturally and organically, without government intervention...If that is correct, cultural diplomacy can only be said to take place when formal diplomats, serving national governments, try to shape and channel this natural flow to advance national interests" (Arndt 2007, XVIII).

The above-quoted definition can very well be applied to India-Poland cultural ties. It can be used to describe the transformation of historical and cultural relations between these two countries into cultural diplomacy. The following sections of the paper will dive deeper into assessing this transformation.

\section{Historical Roots of Cultural Interactions between India and Poland}

An interesting account of history is associated with India Poland relations. It starts with a man named Gasper da Gama, also known as Gaspar de las Indie, born in Poznan, Kingdom of Poland in 1444 (POLIN Museum). Gasper was a Jewish traveller who was taken as a prisoner in Alexandria, sold as a slave and sent to India. While in India, Gaspar got his freedom and entered the service of the ruler of Goa. He then took the name Yusuf Adil. When the Portuguese explorer Vasco da Gama, arrived at the cost of Goa in 1498, no other than Gaspar da Gama was the one to welcome him. Vasco da Gama self-righteously took Gaspar into his service and compelled him to embrace Christianity under the baptismal name of Gaspar da Gama. It was after this encounter with Vasco da Gama, that 
he was also known as Gaspar d'Almeida and Gaspar de las Indias. In 1502 he travelled to India with Vasco da Gama, and later in 1505 as a part of an expedition by Francisco d'Almeida against Calicut, where it is assumed that he may have died in 1510 (Jewish Virtual Library). According to Władysław Góralski, author of the book "Poland- India", Gaspar de Gama is the first Pole to set foot in India, thus setting the stage for the endless exchanges between the two countries. (Góralski 1987).

\section{Writers, Authors and Poets}

The traces of cultural interactions between Poland and India can be found in a history that dates back roughly to $18^{\text {th }}$ century. Adam Mickiewicz (1798-1855), who is regarded as the National poet of Poland, expressed his interest for Indian culture in many of his letters which later became widely known. Mickiewicz believed that Indian culture had many similarities with Slavonic traditions linking the concepts of Atma/ Para-Brahma with the Lithuanian concept of Prażimas. Further, his work 'Dziady' a play regarding a Lithuanian feast to commemorate the dead, mainly the forefathers, is said to be a partial reflection of his studies of Indian classical literary antiquities (Klodkowski 2014, 6). In India, a similar practise is still followed, known as 'Shradhor Pitra Paksha'. It is a practise wherein a spiritual and a ritual offering is commemorated for the ancestors, ending with the offering of food to the Brahmins.

Another important personality from the sphere of Polish literature, Juliusz Słowacki, also shared the same passion for Indian culture. Słowacki found inspiration from the Upanishad's "tat tvam asi" meaning Thou Art That, which according to professor Juliusz Kleiner, can be found in Słowacki's poetic prayer "Genesis out of Spirit". Inspiration from the teachings of Buddhism can also be found in his poem "King-Spirit" (Klodkowski 2014, 7).

Wincenty Lutosławski (1863-1954) is another name associated with propagating Indian culture in Poland through "Yoga". He came up with his own philosophical version of Yoga, after having read a treatise by Vivekananda. He published many articles and magazines which included "East and West", "Vedic Magazine" and "Young India" (Klodkowski $2014,8)$. Apart from these, there are many other Polish poets and writers who took inspiration from Indian literary and philosophical traditions. They include Lange, Kasprowicz, Tetmajer, Sieroszewski, Witkacy and Saliński. Renowned Indian writer Rabindranath Tagore's famous work "Gitanjali" was also translated into a poetic version (Klodkowski 2014, 8-9).

It is an astonishing fact that the chair of Sanskrit was established way back in 1893 at the Jagiellonian University when Poland did not exist as a sovereign state. Furthermore, in 1923 the Indology Department of the Oriental Institute was set up at the University of Warsaw, which is currently the biggest centre for Indian studies in Poland.

\section{Interactions during the Second World War}

Even during World War II, Poland and India managed to interact in unique but important ways. India at the time was under British rule and Poland was engulfed in the unfortunate war. Nevertheless, during such stressful times, India and Poland interacted with each other on several accounts (Kumar 2013, 53). In 1939 Stefan Norblin, a Polish painter, who 
along with his wife had escaped Poland during Nazi invasion, reached the north-west part of India through the routes spanning across Europe. During his stay in India he produced splendid masterpieces of art, after being commissioned by the Maharaja of Jodhpur to paint murals on the walls of the grand palace (Kepa 2012). Norblin, adopted a distinct style of Indo-European visual interpretation by blending Indian traditional content with European styles and techniques (Chatterjee 2013).

Another instance of interaction happened, when Maharaja Digvijay Singh Ji, also known as the Jam Saheb of Nawanagar, offered shelter to Polish children at an orphanage specially created for them in Balchadi in 1942. Maharaja Divijay Singh played an important role by taking care of children by supporting them both materially and emotionally (Kepa 2016). He also convinced other monarchs and noblemen to contribute by funding the settlement of Polish refugees. Simultaneously another Polish settlement was established in Valivade, near Kolhapur, which remained the biggest settlement for Polish refugees in India. It housed around 5000 Poles, and resembled a typical Polish town, with its own administration, church, schools (both elementary and primary level), college, community centres, theatre, craft workshops and a cooperative called "Zgoda" which means accord (Hoffman 2015).

Around the same time, two prominent Poles, Wanda Dynowska and Maurycy Frydman, who adopted Indian names Uma Devi and Swami Bharatananda respectively, asserted India to be their second motherland. These two personalities were close to the leaders of India's independence movement, and also offered services to Dalia Lama. They even established the Biblioteka Polsko-Indyjska- a Polish-India Library, which in 1944 translated Indian religious and philosophical works into Polish (Piotr Klodkowski 2014, 7)

\section{Transforming Cultural Relations to Cultural Diplomacy}

After the establishment of diplomatic ties between India and Poland in 1954, more cultural interactions began to take place. The following year, Indian Prime Minister Jawaharlal Nehru visited Poland, paving the way for bilateral cultural relations that would follow. (Kugiel; Upadhyay 2018, 129). The agreement concerning the cultural cooperation between the People's Republic of Poland and The Republic of India, signed on $27^{\text {th }}$ March 1957, exalted cultural relations between the two countries to cultural diplomacy. The opening sentence of the agreement mentioned the common desire of the President of India and the Council of state of the Republic of Poland to strengthen the bonds of friendship between the two nations, promote cultural relations between India and Poland and develop cooperation in scientific, educational and cultural fields (Ministry of Culture, Government of India 1957).

This formal establishment of cooperation in the area of culture by the respective governments happened on the grounds of previously established organic cultural relations between people from both societies. The definition by Richard Arndt, provided in the earlier section, elucidates clearly that cultural diplomacy takes place when government officials intervene to shape and channel the already existing cultural relations. In doing so, the political will required to transform relations is exhibited. Government transforms the cultural relations into cultural diplomacy, which continues to include organic people-to-people contact as well as channel government policies to promote and share each other's culture. 
The agreement contained seven articles dedicated to the promotion of culture in their respective countries. The articles focused on exchanges between artists, painters, radio broadcasters, students, representatives of science, arts and culture; the organisation of scientific and artistic exhibitions, films, documentaries, music; cooperation between media, journalists, press agencies and editor's offices, and also between scientific and research institutes and artistic and literary associations in both countries. The agreement also mentioned the establishment of cultural institutes in each other's country (Ministry of Culture, Government of India 1957).

The period of the 1960s saw increased cultural activities between India and Poland. As part of the Indo-Polish Cultural Exchange Plan (1964-66), the Polish Exhibition of Theatre Art visited India from March to June in 1966. The exhibition was inaugurated in Delhi on $28^{\text {th }}$ March 1966 by the Deputy Minister of Education, Dr. Mrs. S. Ramachandram. In the same year, the Vice-President of the Union of Polish Writers, Mr. Jerzy Putrament, along with his wife, visited important places in India in November and December (Ministry of Human resource and Development, Government of India 2016).

An Indo-Polish Cultural Exchange Programme for the years 1966-68 was signed in Warsaw on $13^{\text {th }}$ June 1966. As part of this programme, an Exhibition of Polish Graphic Arts and Posters was inaugurated in Delhi on $2^{\text {nd }}$ January 1967 by the Chairman of the Lalit Kala Akademi (Ministry of Human resource and Development, Government of India 2016). The signing of such agreements has proved beneficial in increasing cultural exchanges between the people of the two countries.

In 2005 an important agreement on cooperation between the Ministry of Culture of India and the Ministry of Culture of Poland was signed for the years 2005-2007. The agreement aimed to intensify assistance in the field of culture between India and Poland, based on the provisions of the previously signed agreement on cultural cooperation, of 1957 (Ministry of Culture, Government of India 2005). The agreement was important as it was not only built on the initial effort of transforming relations to diplomacy at the state head level, but also because emphasis was given to dedicated cultural ministries, which could formalise the interaction and carry the relations forward.

\section{Recent Joint Statement on Cultural Engagements}

In 2014 India and Poland agreed to further deepen their cultural ties through a diverse range of activities, such as conservation, museums, archaeology, archives, science museums, and the performing arts (Ministry of Culture, Government of India 2014). This was reflected in the joint statement issued after the meeting between Secretary Culture, Shri Ravindra Singh and the visiting Deputy Minister of Culture and National Heritage of Poland, Prof. Malgorzata Omilanowska, in 2014. The joint statement addressed the importance of culture as a binding factor in the relationship between the two countries. The focus point of the joint statement included,

a) Creation of a Joint Working Group to identify specific deliverables from both sides and develop an operational plan.

b) Poland will provide opportunities to young artists from India to perform at the newly constructed Krysztof Penderecki Luslawice National Music Hall and provide scholarships for emerging talents. 
c) The two countries shall develop collaboration in Museum Management. Emphasis will be given for development of collaboration with the National Science Centre New Delhi.

d) The two shall develop collaboration in archive and Modern Art.

e) The two sides agreed to identify projects for restoration. The Polish side expressed interest in restoration work in Gaya (Ministry of Culture, Government of India 2014).

After the establishment of cultural diplomacy, cultural relations was given a further boost which is reflected in the current level of engagements. The following sections of the paper will focus on the contemporary level of interactions between India and Poland.

\section{Contemporary Cultural Engagements of Poland in India}

Currently, Polish culture in India is reflected in the forms of art, literature, theatre, and business. To facilitate Polish culture among young Indians, the Polish Institute was established in New Delhi in 2012. The Institute operates in the field of visual arts, design, literature, music, theatre, film, architecture, and academic research (Chatterjee 2013). Scholarships are granted to deserving students from Indian universities to study in Poland for a month in summer schools. The idea is to familiarise young Indian students with the Polish language and traditions. Courses on the Polish language have been established at the University of Delhi and Benaras Hindu University. Moreover, dedicated Polish centres have been established in certain universities, for instance, in the Manipal Academy of Higher Education and University of Calcutta. These centres provide excellent exposure to Indian students of Polish history, contemporary politics, and international relations.

Besides this government initiative, a general trend is emerging among the citizens of both countries to foster stronger engagements. Some of the recent developments highlight the positive trend in this aspect. For instance, the Polish airlines LOT recently decided to open the first non-stop direct flight route to India. Flights from Warsaw will now directly go to New Delhi, operating five times a week (Indian Express 2019). According to the LOT airline's CEO Mr Rafal Milczarski, 'this flight's potential is promising as over 8.9 million passengers travelled between India and Europe in the year 2017' (Airways Mag 2019). Poland's position at the centre of Europe makes it a good hub for connectivity between Asia and Europe.

Famous Polish poetry has now found expression in the Hindi language as majority of it has been translated to Hindi. Some of the famous works translated to Hindi include, "Otwarty dom" (Khula ghar) by Czesław Miłosz ; "Obszar pamięci” (Antahkaran ka ayatan) by Zbigniew Herbert ; Może być bez tytułu” (Koi shirshak nahi) by Wisława Szymborska; "W cudzym pięknie" (Parayi sundarta mein) by Adam Zagajewski and "W środku życia" (Jivan ke bichombich) by Tadeusz Różewicz (Klodkowski 2012, 8). This shows that the readers of literature in India are showing greater interest towards central and eastern European cultures, with Poland being the prime example.

Similarly, Polish movies are also making an impact at Indian Film Festivals. Andrzej Wajda, Krzysztof Kieślowski, Krzysztof Zanussi and Roman Polański are just a few of the names whose works have been appreciated and respected in India. Polish Cuisines are slowly gaining attention in India. The restaurant Public Affair in New Delhi now serves Polish Cuisine every Thursday, as tweeted by Adam Burakowski, Polish Ambassador to 
India, who launched a Polish culinary event, 'Delightful Poland' (Twitter 2019). New Delhi also has a Polish Hotel called 'Prince Polonia' which in the 1980s was a popular place to stay for Polish backpackers. Polish journalists Max Cegielski and Janek Simon also launched a project called the 'Polish- Indian Shop'. Through this project they held exhibitions focusing on Polish travellers to India, which included painters, musicians, poets, and mountaineers who visited India during the 1960s-70s. The positive experience shared by those Polish travellers has shaped a positive image of India, resonating in the acceptance and acknowledgement of concepts like Hinduism, Buddhism, Yoga and the Hare Krishna movement- which has managed to attract a substantial number of followers in Poland (Bhura 2017).

Polish cosmetic brand Inglot is also planning to target the Indian market, with the aim of opening 100 stores by 2020 (Fashion Forward Trend 2016). Currently, the brand is available on major Indian online stores like "Jabong", Myntra and Nykaa. Inglot is a widely popular cosmetic brand, in European and American markets and is gaining the same reputation in India.

Football is another way through which Poland is making its impact on the Indian sporting community. Though football is not as popular as cricket in India, it is slowly gaining popularity in different Indian states, for instance in West Bengal, where the first football club 'Calcutta FC' was established in 1872, (Calcutta Cricket and Football Club). With the establishment of the Indian Super League tournament, the popularity of football in India has increase manifoldly and more and more people are taking note of the talent in the country. Through this development Poland has sought to collaborate with young Indian talent as it has ample expertise in the game. A non-governmental Indo Polish Sports and Culture Council was established in 2016, which aims to promote relations between the two countries through cooperation in sports. Since its establishment, more than four UEFA Pro License coaches have visited India for offering training. In September 2019, around 12 youngsters from India trained in Warsaw, as the Council has a branch in Warsaw (Times of India 2019).

Nevertheless, given the initiatives, it is important to remember that Poland as a country has had little experience in establishing its political presence around the world. It is only in recent years that Polish diplomacy has managed to cultivate relations with important countries in the international system (Klodkowski 2012). Taking this into account, it must be noted that awareness about Poland in India is limited to small sections of the society, as per research conducted by scholar Patryk Kugiel (Kugiel 2013, 4).

However, that is steadily changing due to the emphasis given by Indian media to Poland. News about Poland is now getting featured in Indian newspapers and channels. Although one could argue that the extent of coverage is not as detailed and extensive when compared to countries like the United States or China, the fact that Indian news media is taking note of Poland is a shift from earlier times when there was no focus on Poland at all. An important research on the emphasis of Poland in Indian media was conducted by scholar Patryk Kugiel. According to his research in the archives of a leading Indian newspaper, the Times of India, Poland was prominently mentioned 148 times in the headlines between the 2017-18. For Kugiel, a sharp increase in featuring Poland in Indian newspapers could be because of promotional campaigns and cultural co-operation programmes co-ordinated by Polish organisations such as the Polish Institute of Culture (Kugiel 2019, 134). 
Apart from traditional media, social media is also playing an active role in placing Poland in Indian minds. In 2007 the Indian diaspora in Poland was around 3000 (The Economic Times 2007). By 2019, the number had grown to 12000 (NRIOL 2020). Active usage of social media by the Indian diaspora has disseminated information about Poland in India, which has generated curiosity and is reflected in the growing numbers of Indians applying for Polish visas. According to the data published by travel trend today website for 2018, around 16,000 Indians visited Poland which has led to establishment of Visa Application Centres in important cities in India to address the growing number of applications (T3 Network 2019). Again, it is important to point out that knowledge about Poland in India is only steadily increasing.

The actual percentage of Indians who know about Poland is still very low. However, given the positive trend in the relations, a joint effort by the governments in this area could yield positive results in the future (Kugiel; Pędziwiatr 2014, 33-34).

\section{The Influence of Indian Culture in Contemporary Poland}

\section{Bollywood and Tourism}

Bollywood is one of the largest movie producing industries in the world. In fact, India is the largest producer of films in terms of quantity. According to data released by UNESCO in 2015, developing countries accounted for 59\% of global movie production with the booming cinema industry in India being the main driving force (UNESCO 2017). The vast market of movie making in India is lucrative for countries across the globe. Especially, the stunning success of the Guinness World Record-breaking Bollywood movie Dilwale Dulhaniya Le Jayenge (1995) turned Switzerland into one of the most popular vacation spots for well-heeled Indian tourists. Similar was the case with the movie "Zindagi na milegi dobara". The majority of the movie was shot in Spain and attracted Indian tourists. especially to the La Tomatina festival, which boosted Spanish tourism by 32\% just after the film's release (CNN 2011). "Befikre", a movie shot in France, increased the flow of Indian tourists to France, according to the French ministry in India. (Business Standard, 2019). Therefore, when countries like Switzerland, Spain and France are actively involved in campaigning for Bollywood movies given its lucrative tourism business opportunities, Poland could also benefit immensely given its stunning natural beauty and cost effectiveness compared to many other European countries.

In Poland, Indian cinema has started to gain popularity. Although Indian classical dance and music shows are regularly being held, with growing number of people showing interest in them, the main driving force however, has been Bollywood. Several Indian film makers have started shooting movies in Poland. For instance, a popular movie called 'Fanaa' was shot in the beautiful Zakopane- the winter capital of Poland. The location was preferred for scenes which required the movie to show parts of Kashmir, but due to the constant insurgency in the Kashmir valley, the movie could not be shot there. A couple of years after this movie, Poland became a popular destination for Indian movie producers. (Iwanek 2015). Recent Bollywood movies like 'Shaandaar' which was shot in Kozłówka palace in eastern Poland and 'Kick' which featured locations around the capital of Poland, Warsaw, have paved the way for several other movies to choose their destination of choice 
as Poland. Popular movies that have been shot in Poland include Bangistan, Aazaan, Yah Jo Hai Mohabbat, and 24 (Tamil).

Three institutions have played a strong role in bringing Indian movie makers to Poland. These include the Polish Tourism Organization (Polska Organizacja Turystyki), Film Polska Productions, and the Kraków Festival Office (Krakowskie Biuro Festiwalowe). The Kraków Festival Office has played a fundamental role in the promotion of Krakow city. The Polish Tourism Organization has been successful in wooing Indian movie producers since 2009 and in 2012, the organisation started the "I like Poland" campaign, which focused on the Japanese, Chinese and Indian tourist markets, again taking film producers into account. Interestingly the success of the organisation was showcased in attracting the producers of the movie 'Kick', which the organisation did so by offering financial incentives and permissions for shooting at different locations around the capital (Iwanek 2015). Just as Bollywood is making its impact, Indian songs and dances are too playing their role in familiarising Polish people with popular Indian culture. Flash mob dances- a modern impromptu act of dance, which is quite unique in itself, now frequently happens in popular spots around the city centre or near malls (Rizmedhi 2013). Although it may not be considered the best representation of the country's overall culture, it serves as a unique way of showcasing the happy and young spirited side of the Indian people and the welcoming attitude of Polish society towards such an act of diversity.

\section{ISCKON and Famous Indian leaders}

Hints of Indian culture are also seen in Poland through the religious International Society for Krishna Consciousness (ISKCON), also known as the Hare Krishna movement. The Hare Krishna movement is widely popular among the foreign audience, drawing huge numbers of followers from western countries, including the United States, Great Britain, Germany, and France to name a few. The Krishna consciousness movement is also slowly gaining followers in Poland, with the movement establishing temples in three places in Poland; Czarnów, Warszawa, and Wrocław (ISKCON 2016). Members of the ISKCON society, walking on the streets of Warsaw chanting "Hare Rama Hare Krishna" is no longer an uncommon sight.

There are streets in Poland commemorating Indian political, and famous personalities. In Warsaw there are streets named after Mahatma Gandhi, Jawaharlal Nehru, Indira Gandhi, Rabindranath Tagore, and Mother Teresa. Streets named after Mahatma Gandhi can also be found in Kraków and Łódź along with his bust which is placed in the library of University of Warsaw (Embassy of India, 2016). A monument commemorating Jam Saheb Digvijaysinhji Ranjitsinhji Jadeja of Nawanagar, was unveiled on 31 October 2014 at the Square of the Good Maharaja, Ochota District, Warsaw, Poland. In fact, a Polish school is named after him. Further, on 11 March 2016, the Polish Parliament unanimously passed a resolution honouring the kindness and generosity of the Maharaja on the $50^{\text {th }}$ anniversary of his death (the Embassy of India, 2016).

\section{Yoga and Ayurveda}

The Indian practices of Yoga and Ayurveda are also gaining momentum in Poland. The $2^{\text {nd }}$ International Yoga Day was celebrated in June 2016, across 25 Polish cities. The Uni- 
versity of Opole in collaboration with the Ayurveda and Yoga Centre of Sulislaw offers degree courses in Ayurveda and Yoga. From India, scholarships called "Ayush" are offered to Polish students to study Ayurveda and Yoga in India (the Embassy of India 2016). Regular, free of cost Yoga classes are conducted by the Embassy of India in Warsaw.

\section{Student exchange and friendship societies}

To develop people-to-people contact, especially among the younger populations, India and Poland have decided to collaborate on various student exchange programmes and establish friendship societies. Students from Poland are given scholarships under the Indian Council for Cultural Relations (ICCR) schemes every year to study in India. Furthermore, Kendriya Hindi Sansthan, located in Arga provides four scholarships to Polish students every year, to study Hindi. Similarly, Poland has reciprocated by providing university level scholarships to several Indian students. Indian students can also take the benefits of studying in private universities in areas such as medicine, engineering, town planning, shipbuilding, and coalmining. Given the exchange collaboration between the two counties, the number of students choosing Poland to study has increased drastically.

Juxtaposing the success of student exchange programs, are also the Indo-Polish friendship societies which were established with the aim of promoting Indian culture and solidifying people-to-people contacts at the grass roots level. Some of the popular societies include, (i) the Indo-Polish Cultural Committee (IPCC); (ii) the Indian Association of Poland (IAP); (iii) the Mantra Culture \& Community Centre (MCCC); (iv) Friends of India in Wroclaw (FIW); (v) Friends of India in Poland, Warsaw; (vi) the India International Foundation, Warsaw; (vii) the Indian Culture \& Sport Centre, Warsaw; and (viii) the Indo-Polish Writers Association (the Embassy of India).

\section{Implications of Cultural Diplomacy beyond Culture, Politics, Economics and Defence}

As per the above-mentioned account of developments, it can safely be inferred that both India and Poland are now initiating, as well as reciprocating each other's efforts to build a meaningful relationship. These efforts are reflected in their current political, economic and defence engagements. In the political sphere, for instance, Poland has committed to support India's place as a permanent member of the UNSC in case of any future reforms. Poland is also in favour of India's non-permanent seat at the Security Council for 2021-2022. India, on the other hand, has reciprocated by supporting Poland's candidature for a non-permanent seat at the UNSC (Ministry of External Affairs, Government of India 2019). At the recent UNSC discussion on the Kashmir issue, Poland took the same stance as that of the US and France, signifying that the matter of Kashmir should be bilaterally discussed between India and Pakistan. Warsaw is also the sponsor of the UNSC Resolution 1267 which imposes sanctions and restrictions on the Pakistani organization Jaish-e-Muhammad along with its leader Masood Azhar, responsible for the terrorist attack in Pulwama in February 2019 (Ministry of External Affairs, Government of India 2019).

Political relations got a further boost when External Affairs Minister Subrahmanyam Jaishankar visited Poland in 2019. The visit was particularly important as it was the first 
such visit by a foreign head since 1987. The two sides acknowledged each other's importance with the wish of having a long-lasting friendship. Foreign Minister S. Jaishankar also expressed India's willingness to engage more with Poland, especially in the Visegrad format, signifying that India not only acknowledged Poland's role as an emerging power in Central Europe, but also that India was ready to engage with important European countries bilaterally, and not just under the ambit of the European Union. The visit also outlined certain key areas where the two sides agreed to focus and build a strong engagement. These included, but were not limited to, bilateral political co-operation, economy, education, culture and strategic issues like peace and security, terrorism, and humanitarian issues. The two sides also agreed on the importance on having a strong strategic partnership between the European Union and India and expressed support for an EU-India agenda which would benefit India and Poland bilaterally (Iwanek 2019)

On the economic front, a number of economic agreements already exist between India and Poland (Poland in India 2020). Bilateral trade between Poland and India has also been growing significantly in recent years, and presently stands at approximately \$3billion (Chaudhury 2019). Furthermore, a significantly large foreign direct investment in India from the European Union is due to a Polish company CAN-PACK S.A., which established an aluminium and glass beverage packaging facility in Aurangabad in Maharashtra with the view of expanding operations in India (Chaudhury 2019). The 2016 visit by Indian Vice President Hamid Ansari was based on the premise that India views Poland as an important emerging economy, not just in Europe, but also globally. Bilateral economic engagement between India and Poland has increase exponentially to a point where Poland is India's largest economic partner in Central Europe (PIB Government of India 2017). India benefits from a positive trade balance with the region, as Indian exports have been increasing much faster than its imports from the Central and Eastern European (CEE) region. Particularly from Poland, Indian imports have focused on heavy machinery, mechanical and electronic devices along with arms and defence equipment, while it exports textiles, garments, footwear, organic chemicals, vehicles, automobile parts and common metals and stones. Along with participation in Make in India week in 2016, Poland has also launched the 'Go India' programme- to facilitate direct contacts between Polish companies with their India counterparts. (Kugiel; Upadhyay, 2018). There is huge potential for increasing bilateral trade between the two sides and the governments in the past few years have encouraged business leaders to broaden cooperation in promising new sectors like coal mining, food processing and defence (the Indian Embassy Warsaw 2017).

In terms of engagement in the defence sector, the kind of relationship that India and Poland want to develop was best expressed by Secretary of State in the Ministry of National Defence Mr Janusz Władysław Zemke in 2004, when he stated that Poland is not seeking just a buyer-seller relationship in the defence field with India, but a long term strategic partnership in Asia (Mohan 2004). In this regard, the two sides are keen on building an enduring defence partnership that includes joint research, development, and production of weapons systems. Prior to his statement, a Memorandum of Understanding on Defence Cooperation was signed between India and Poland in February 2003 during the visit of Polish Prime Minister Leszek Miller to India (Ministry of External Affairs 2003). Simultaneously India has awarded contracts worth $\$ 600$ million to Poland for the modernisation of tanks and the acquisition of air defence missiles ((PTI 2008). It is important to note that India has traditionally relied on Russia for its defence needs as the Soviet Union was one 
of its strongest partners during the Cold War. However, since the end of the Cold War and since India's economic liberalisation policy of 1991, New Delhi has looked to diversify its buyers and reduce its dependency on Russia. In this regard, Poland can take advantage of India's growing defence needs and explore opportunities in defence manufacturing under initiatives like Make in India.

Be it economic, political or defence it can clearly be seen that both sides express high levels of commitment to each other and not just customary engagements. The combination of social and cultural understanding, along with political and economic engagement, contributes to a maturing partnership. (Kugiel; Upadhaya, 2012). In international relations, partnerships that are formed purely on the basis of common interests or common threats don't last a long period as interests and threats are both susceptible to undergoing change with time, and hence such structures may not survive beyond a point. The case of India and Poland is unique in this regard as the relationship is based on goodwill from the past marked with common experiences of struggles in forming a nation. This mutual goodwill is result of the past cultural relations that created favourable views between the people of both the countries even in its limited form.

\section{Conclusion}

Cultural diplomacy is an important instrument of public diplomacy. It helps to reach out to different sections of society, that otherwise cannot be reached through the usual diplomatic channels. The people-to-people connection between India and Poland has been enhanced by the various governmental initiatives that have taken place over the course of time. Engagement at the governmental level has transformed cultural relations into cultural diplomacy. At present Poland and India are engaging with each other through Track I and Track II diplomacy.

Citizens of both the countries are well connected with each other through literature, common elements of history, academic cooperation, scientific research and development, drama, dance, art, student exchanges and so on. In the recent past, India's engagement with European countries was primarily through the lens of the European Union. However, India's foreign policy under the new government has focused on developing strong bilateral ties with all important countries around the world. In this case, India acknowledges Poland's importance as a major player in Central Europe and developing ties with Warsaw provides India an opportunity to open up to other countries in the region. Similarly, for Poland, India too is an important country to develop ties with. Given India's demographics and growing business size, it could be a lucrative destination for Polish investment and trade. Furthermore, Polish diplomacy in the past few years has focused on building ties with countries in Asia and the pacific region. In this context, India, a strong democratic power, perfectly fits the picture.

Although there is no strategic partnership per se, between India and Poland, there is a sense of growing urgency within both the countries to deepen their relationship. This puts impetus on cultural diplomacy, as it provides a strong foundational block on which the ties could be nurtured. Cultural diplomacy, in other words, can help transcend India-Poland relations to other beneficial and important aspects of bilateral engagement. In fact, in certain aspects the fruits of cultural diplomacy have started to show as both the countries have backed each other at times of international events and discussions. 
Hence, it can be concluded that what started as cultural relations have now transformed into cultural diplomacy paving the way for the two sides to further broaden their ambit of future engagements.

\section{References}

Arndt, R. T. (2006). The First Resort of Kings: American Cultural Diplomacy in the Twentieth Century. United States: Potomac books.

Bhura, S. (2017). Warsaw Exhibition Turns Spotlight on Golden Age of Polish-India Relations. Live Mint. Retrieved September 13, 2019 from https://www.livemint.com/ Leisure/BuWiAlKdZc0t1QqWj1dcaM/Warsaw-exhibition-turns-spotlight-on-golden-age-of-PolishIn.html

Burakowski, A. (2018). Official Twitter Account of Polish Ambassador to India. Twitter. Retrieved September 13, 2019, from https://twitter.com/Adam_Burakowski/status/1072301541569323008

Calcutta Cricket and Football Club. CCFC. Retrieved August 12, 2019, from https:// ccfc1792.com/history.php

Chaudhury, D.R. (2019). Indian Foreign Minister Visits Poland ahead of Direct Delhi-Warsaw Flight. The Economic Times. Retrieved March 11, 2020, from https:// economictimes.indiatimes.com/news/politics-and-nation/indian-foreign-minister-visits-poland-ahead-ofdirectdelhiwarsawflight/articleshow/70882976.cms?utm_ source $=$ contentofinterest\&utm_medium $=$ text\&utm_campaign $=$ cppst

Chatterjee. M. (2013). Poland's 60 years in India- Spotlight on Soft Power Showcases. Blogspot. Retrieved September 5, 2019, from http://madhu-madhusree.blogspot.in/2013/08/ polands-60-years-in-india-spotlight-on.html

Embassy of India, Warsaw. (2017). India-Poland Relations. Embassy of India, Warsaw. Retrieved August 18, 2019, from https://www.indianembassywarsaw.gov.in/eoi. php?id=Pol_relat

Embassy of India. (2017). Vice President of India Concludes Productive Visit to Poland. Government of India. Retrieved March 15, 2020, from https://www.indianembassywarsaw.gov.in/alert_detail.php?id=15

ENS Economic Bureau. (2019). Lot Polish Airlines Launches Direct Flight from Delhi to Warsaw. Indian Express. Retrieved September 14, 2019, from https://indianexpress. com/article/business/aviation/lot-polish-airlines-launches-direct-flight-from-delhi-towarsaw-5993954/

Góralski, W. (1987). Poland- India: Political, Economic and Cultural Problems. Warsaw: Polish Interpress Agency.

Harjani, P. (2011). India's tourists flock to Spain. CNN. Retrieved August 12, 2019, from http://travel.cnn.com/mumbai/life/indian-movie-boosts-spanish-tourism-694426/

Hoffman, A. (2015). Fundacja Kresy Historii Warsaw. Kresy Historii. Retrieved August 12, 2019, from https://kresyhistorii.pl/valivade/?page_id=4384\&lang=en

ISKCON Centres. Worldwide directory of official ISKCON Centres \& Branches. ISKCON. Retrieved August 18, 2019, from http://centers.iskcondesiretree.com/poland/

Inglot Eyes 100 Stores in India by 2020. (2016). Fashion Forward Trends. Retrieved September 12, 2019, from http://www.fashionforwardtrends.com/news/inglot-eyes-100stores-in-india-by-2020/ 
International Bollywood Flash Mob Dance in Katowice 2016. Poland Galeria Katowicka. YouTube. Retrieved August 26, 2019, from https://www.youtube.com/watch?v=RYGBsZ$2 \mathrm{~b} 5 \mathrm{Pg}$

Iwanek, K. (2015). Kracowood: Bollywood's New-Found Love Affair with Poland. The Diplomat. Retrieved August 26, 2019,from https://thediplomat.com/2015/07/kracowood-bollywoods-new-found-love-affair-with-poland/

Iwanek, K. (2019). Revising Warsaw-New Delhi Ties After Indian the Foreign Minister's Visit to Poland. The Diplomat. Retrieved March 11, 2020, from https://thediplomat. com/2019/09/revising-warsaw-new-delhi-ties-after-indian-the-foreign-ministers-visit-to-poland/

Jewish Virtual Library. Gaspar Da Gama. Jewish Virtual Library. Retrieved August 18, 2019, from https://www.jewishvirtuallibrary.org/gaspar-da-gama

Kępa, M. (2016). The Maharaja Who Saved Hundreds of Polish Orphans. Culture.PL. Retrieved September 10, 2019, from http://culture.pl/en/article/the-maharaja-who-savedhundreds-of-polish-orphans

Kępa, M. (2012). Stefan Norblin, Culture.PL. Retrieved September 5, 2019, fromhttp://culture.pl/en/artist/stefan-norblin

Kugiel, P. (2013). 'What does India Think about Poland'. The Polish Institute of International Affairs. 63, 1-7.

Kugiel, P; Upadhyay, D.K. "India and Central and Eastern Europe: Post-Cold War Engagement." International Studies 54, no. 1-4 (January 2017): 127-43.

Kugiel, P; Pędziwiatr, K. (2014). The Indian Diaspora and Poland-India Relations. Warsaw: Polski Instytut Spraw Międzynarodowych.

Kugiel. P. (2019). Indian Perceptions of Poland. In Rajendra K Jain and ed(s). Changing Indian Images of the European Union. United Kingdom: Palgrave Macmillan, 134.

Kumar, P. (2013). Evaluation of Indo-Polish Relations: A Realistic Approach under Legal Framework of Free Trade Area (FTA).

Kłodkowski, P .2014. Poland and India: Towards a Strategic Partnership, a Subjective Perspective. In Patryk Kugiel and ed(s). India-Poland Relations in the $21^{\text {st }}$ Century: Vistas for Future Cooperation. New Delhi: Vij Books, 6.

Kłodkowski, P. (2012). 'Story of the Clashing Images of the Country. The Case of India's Image at Home and in Poland'. Polish Sociological Review. 178, 303-324.

Mohan, C. R. (2004), India, Poland Deepen Defence Ties. The Hindu. Retrieved September 10, 2019, from https://www.thehindu.com/todays-paper/tp-national/india-poland-deepen-defence-ties/article27579032.ece

Ministry of Culture. (1957). Cultural Agreement with Poland. Government of India. Retrieved September 11, 2019, from http://www.indiaculture.nic.in/sites/default/files/Cultural\%20Agreement/113.pdf

Ministry of Culture. (2019). Mission Statement. Government of India. Retrieved September 12, 2019, from https://www.indiaculture.nic.in/mission-statement

Ministry of Foreign Affairs. (2019). Department of Public and Cultural Diplomacy. Government of Poland. Retrieved September 12, 2019, from https://msz.gov.pl/en/ministry/ organisation/organisational_units_/department_of_public_and_cultural_diplomacy

Ministry of Culture. (2005). Cultural Agreement with Poland. Government of India. Retrieved September 12, 2019, from http://www.indiaculture.nic.in/sites/default/files/cultural_rel/poland.pdf 
Ministry of Human Resource and Development. (2016). Cultural Relations with Foreign Countries. Government of India. Retrieved September 12, 2019, from http://www.teindia.nic.in/mhrd/50yrsedu/12/8i/6U/8I6U0G01.htm

Ministry of Culture. (2014). Press Information Bureau. Government of India. Retrieved September 12, 2019, from http://pib.nic.in/newsite/PrintRelease.aspx?relid=103899

Ministry of External Affairs. (2019). Joint Statement of the Ministers of Foreign Affairs of India and Poland. Government of India. Retrieved March 11, 2020, from https:// www.mea.gov.in/bilateral-documents.htm?dtl/31777/Joint+Statement+of+the+Ministers+of+Foreign+Affairs+of+India+and+Poland

Ministry of External Affairs. (2003). Prime Minister Leszek Miller's Visit to India 15-18 February 2003. Government of India. Retrieved March 11, 2020, from https://www.mea. gov.in/other.htm?dtl/20180/Prime+Minister+Leszek+Millers+visit+to+India+1518+February+

NRIOL. (2020). Overseas Indian Population. Retrieved March 14, 2020, from https:// www.nriol.com/indiandiaspora/statistics-indians-abroad.asp

One India. (2010). India, Poland to sign agreement on cultural exchange programme on Tuesday. One India. Retrieved September 12, 2019, fromhttp://www.oneindia. com/2010/09/06/indiapoland-to-sign-agreement-on-cultural-exchangeprogr.html

Oxford Dictionaries. (2016). Culture: Definition of Culture in Oxford Dictionary. Retrieved September 12, 2019, fromhttps://en.oxforddictionaries.com/definition/culture

POLIN Museum of the History of the Polish Jews (n.d.) Museum label for Damião de Góis, Chronicle of the Most Happy King Dom Manuel, $16^{\text {th }}$ century. Gallery 2: First Encounters, 965-1500. Warsaw, Poland.

Polish Institute. About US. Polish Institute. Retrieved September 12, 2019, from http:// polishinstitute.in/about-us/.

PTI. (2019). 12 Young Footballer to Train In Warsaw under Indo-Polish Exchange Programme. Times of India. Retrieved September 12, 2019, from https:/timesofindia.indiatimes.com/sports/football/top-stories/12-young-footballers-to-train-in-warsaw-under-indo-polish-exchange-programme/articleshow/71035535.cms PTI

PTI. (2019). Number of Indian tourists who visited France in 2018 could cross 8 lakh figure: Envoy. Business Standard. Retrieved September 12, 2019 from https://www.business-standard.com/article/pti-stories/number-of-indian-tourists-who-visited-francein-2018-could-cross-8-lakh-figure-envoy-119042501085_1.html

Poland in India. (2020). India. Republic of Poland. Retrieved March 11, 2020, fromhttps:// www.gov.pl/web/india/bilateral-relations

Press Information Bureau. (2017). India is a natural destination for markets and business opportunities for Poland: Vice President. Government of India. Retrieved March 15, 2020, from https://pib.gov.in/newsite/printrelease.aspx?relid=161358

Rivera, T. (2015). Distinguishing Cultural Relations from Cultural Diplomacy: The British Council's Relationship with her Majesty's Government. Los Angeles: Figueroa Press.

Rizmehdi. (2013). The First Bollywood Flash Mob in Poland. YouTube. Retrieved September 12, 2019, from https://www.youtube.com/watch?v=eFP0Ko1IXzw

Stokes, J. (2013). Indian Culture Takes Root in Poland.Krakow Post. Retrieved August 26, 2019,from http://www.krakowpost.com/6859/2013/07/indian-culture-takes-rootin-poland 
Taylor, R. (1988). Cultural Diplomacy-The Future. In Agni Vlavianos-Arvanitis. Biopolitics -The Bio-Environment. vol. II (presented at the Biopolitics: The Bio-Environment-Bios in the Next Millennium. Greece: Biopolitics International Organisation.

TNN. (2007). Poland Next Hot Spot for Indian Workers in Europe. The Economic Times. Retrieved March 10, 2020, from https://economictimes.indiatimes.com/pravasi-bhartiya/poland-next-hot-spot-for-indian-workers-in-europe/articleshow/2699503.cms?from $=\mathrm{mdr}$

T3 New Network. (2019). Polish Visa Services Now Available In New Delhi and Mumbai. Travel Trends Today. Retrieved March 10, 2020, from https://www.traveltrendstoday. in/news/international/item/7969-polish-visa-services-now-available-in-new-delhiand-mumbai

UNESCO. (2017). Cinema Data Release. Institute for Statistics. UNESCO. Retrieved September 14, 2019, fromhttp://uis.unesco.org/en/news/cinema-data-release

Winton, J. (2019). LOT Polish Grows: Launches 787 Flights to India. Airwaysmag. Retrieved September 14, 2019, from https://airwaysmag.com/airlines/lot-polish-grows787-flights-to-india/ 